\title{
A Study of Chinese Online Cause-Related Marketing: The Effects of Perceived Benefits on Consumer Attitudes and Participation and the Moderating Effect of Privacy Concerns
}

\author{
Qi Wang ${ }^{1}$ and Seong-Yeon Park ${ }^{2 *}$ \\ School of Business, Ewha Womans University, Korea \\ ${ }^{1}$ wangqi9410@outlook.com, ${ }^{2}$ rsypark@ewha.ac.kr -mail (Correspondingauthor)
}

\begin{abstract}
The rapid development of Internet technology has led cause-related marketing become more diverse. It is important to understand what kinds of cause-related marketing campaigns consumers like. The purpose of this study is to analyze the critical role of perceived benefits and privacy concerns on consumer participation in online cause-related marketing activities. The questionnaires were administered to two groups: experienced groups and inexperienced groups according to respondents' experiences in cause-related marketing activities. For those who had participated in online cause-related marketing campaigns, the three types of perceived benefits (functional benefits, experiential benefits, symbolic benefits) positively affected consumers' attitudes towards the activities and positively affected their participation. The influence of symbolic benefits on attitudes was strengthened by privacy concerns significantly and the influence of functional benefits was weakened by privacy concerns. For people who had not participated in online cause-related marketing campaigns, only perceived symbolic benefits and experiential benefits positively influenced their attitudes towards campaigns, and positively affected their participation intention. The influence of symbolic benefits on attitudes was strengthened by privacy concerns significantly. The results of this study provide new path in the fields of online cause-related marketing. It offers a step forward in clarifying how consumers perceive online cause-related marketing and the moderating role of privacy concerns. It also provides suggestions for companies to use cause-related marketing more effectively.
\end{abstract}

Keywords: Cause-related marketing, consumer attitude, consumer participation, perceived benefits, privacy concerns. 


\section{Introduction}

As a representative and practical method of corporate social responsibility, causerelated marketing combines socially responsible activities with business activities to carry out co-value creation with consumers (Varadarajan \& Menon, 1988). Because it can create both social value and economic value, cause-related marketing attracts wide attention from companies and scholars. However, not all examples of causerelated marketing are successful cases. It is necessary to construct a cause-related marketing strategy that can guide consumers to have good attitudes toward a company and its activities. As cause-related marketing becomes more common and is combined with Internet technology, consumers face more choices about which companies to support. Therefore, it is essential to research choice motivations of consumers.

Existing Chinese research about cause-related marketing has found that brandcause fit, information reliability, and customer trust are important factors that influence consumers' attitudes (Qi \& Seong-Yeon, 2020; Jiangfeng \& Zhilong; Xiangming, 2016; Kunzhang et.al, 2009). But, in order to provide companies with a more comprehensive direction for developing these campaigns, it is important to investigate the effect of perceived benefits so as to understand what kind of benefits motivate consumers more. Meanwhile, Internet technology also brings risks, such as personal information disclosure. Consumers' privacy concerns about Internet services have been considered as an important criterion when developing customized services and have been researched in multiple studies (Jingtao \& Lidong, 2019). However, privacy concerns have not been examined with online causerelated marketing.

This research discusses the influence of perceived benefits (functional, experiential and symbolic) of Internet cause-related marketing on consumer attitudes and consumer participation, and the moderating effect of consumers' privacy concerns in this process. This paper will enrich cause-related marketing research, provide a deeper understanding of consumers' motives when participating in cause-related marketing activities, and offer suggestions for companies to use cause-related marketing more effectively.

\section{Theoretical Background}

\subsection{Cause-related Marketing}

Varadarajan and Menon, representative researchers in cause-related marketing, defined cause-related marketing as marketing activities of companies that donate a specified amount to a designated cause when consumers participate in companies' revenue-providing exchange activities. In contrast to cause marketing, cause-related marketing can create both social and economic value simultaneously. Cause marketing refers to marketing activities that aim to improve the effects of publicity 
rather than making money. For cause marketing, social value is more important than economic value (Philip \& Nancy, 2005).

One of the earliest and most famous practices of cause-related marketing in China was Nongfu Spring's 1 Fen Campaign in 2001. Nonfu Spring, a manufacturer of drinking water, used its campaign to raise money for a Beijing Olympic bid. Nongfu Spring donated one fen ( 0.01 yuan) to the bid every time a customer bought a bottle of water. Thanks to the enthusiasm of the Chinese people for the Olympics, 1 Fen campaign received a warm welcome, and it helped Nongfu Spring become the largest company in the drinking water market in China (Feiyun \& Bing, 2015).

Chinese research on cause-related marketing dates back to 2002. Based on the research of Varadarajan and Menon, Lu and Li originated the concept of causerelated marketing in China and defined it as marketing activities that combine product distribution with public welfare. Subsequently, Gao emphasized the importance of cause-related marketing for China.

In 2012, China issued the Charity Law, and public welfare began to develop prosperously. In 2015, during the Twelfth National People's Congress, Premier Keqiang Li proposed the "Internet plus" strategy, suggesting that all industries in China could actively integrate Internet technology. During the 2016 China's Charitable Conference, the chairman Yong-guang $\mathrm{Xu}$ stressed that Chinese public welfare establishments should flexibly make use of Internet technology. By June 2019 , the number of Chinese netizens increased to 0.58 billion and the Internet penetration rate increased to $61.2 \%$, with netizens ages 10 to 39 occupying $65 \%$. According to Nielsen's investigation of Chinese young people in 2017, 88.9\% of Chinese people aging from 18 to 20 pay attention to public welfare. Young people in their twenties and thirties are becoming new consumers in the Chinese public welfare industry. When participating in public welfare activities, these young consumers not only require the activities to efficiently solve social problems; they also demand convenience, entertainment, and other benefits.

Under this background, in 2016, Alipay, a mobile payment software, sponsored a marketing campaign named Ant Forest to add greenery to desert areas. Ant Forest users were encouraged to record their low-carbon footprint through daily actions like taking public transportation, shopping online and reading online. For each action, users received "green energy" points, and when they accumulated a certain number of points, an actual tree was planted their own name, sponsored by Alipay. Users could choose to protect a certain size of conservation land on the Ant Forest platform and could view images of their trees in real-time via satellite (Yi and Xuemei, 2018). This campaign successfully increased the number of users and user viscosity for Alipay. The company received a 2019 Champions of the Earth award, the UN's highest environmental honor.

The campaign was a great success and brought new attention to cause-related 
marketing in China. Ant Forest, which used Internet technology, further developed cause-related marketing, and efficiently enhanced consumers' initiative, successfully attracted young consumers. At the same time, Ant Forest made waves in academic circles. $\mathrm{Hu}$ and Zhang analysed the gamified publicity strategies of Ant Forest and advised companies to actively apply Internet technology to innovate new marketing methods. Hu explained that the new type of public welfare activity, using instantaneity and entertainment like Ant Forest, could efficiently prompt young people to engage in environmental protection. Zhu discovered that the perceived usability, serviceability and reliability of Ant Forest were key factors that actively influenced consumers' participation willingness.

After the success of Ant Forest, the popularity of online cause-related marketing increased, resulting in campaigns such as WeChat's Donating Steps and Tencent News' Donating Reading Time. As consumers gain more choices, companies are also faced with more fierce competition, so it is necessary for companies to have a good understanding of consumers' preferred types of cause-related marketing. This research proposes that benefits perceived by consumers in Internet cause-related marketing are consumers' dominant motives, and investigates how these benefits influence consumer attitudes and participation in cause-related marketing.

\subsection{Perceived Benefits}

Benefits refer to things that consumers get from products or services. When consumers consume products or services, the products and services are endowed with a series of attributes with individual meaning that produce some subjective requirements or expectations (Keller \& Kevin, 1993). Benefits that consumers expect to receive are those that create value for them through consuming products or services, and will vary because of different individual values and consumption modes (Peter et.al, 1987).

There are multiple dimensions of perceived benefits. Park, Jaworski and MacInnis (Park et.al, 1986) divided perceived benefits into three dimensions: functional, experiential and symbolic benefits. Sheth, Newman and Gross divided product benefits into functional, emotional, social, conditional, and epistemic benefits, proposing five consumption values that influence consumers' choice behaviors. Based on Sheth, Newman and Gross' study, Lai added three benefits: aesthetic, hedonic and holistic benefits. The current research, based on the three dimensions proposed by Park, Jaworski and MacInnis, investigates the relationship between perceived benefits and consumer attitudes based on functional, experiential and symbolic benefits.

Functional benefits are defined as the benefits that help consumers solve or avoid problems. The most essential benefits are those that consumers can get from products or services (Keller \& Kevin, 1993). In the research of Yoo, Divita and Kim, 
functional benefits referred to the benefits that make consumers pursue the highest value with lowest cost.

Experiential benefits include sensory satisfaction and epistemic satisfaction (Park et.al, 1986). Sensory satisfaction refers to the ability of products to change consumers' emotions by providing a sense of interest, happiness and excitement, while epistemic satisfaction refers to the ability of products to satisfy consumers' curiosity and thirst for knowledge through providing variety and novelty (Do-seong et.al, 2013).

Symbolic benefits refer to benefits that satisfy consumers' internal motivation to improve themselves, promote their social status, or bring themselves into a group they want to join (Keller \& Kevin, 1993). As social individuals, people may face demands in order to be accepted by a certain group. Therefore, symbolic benefits refer to the abilities that products or services are equipped with that help consumers to be affirmed by important people in order to improve their status in a group (Park et.al, 1986).

\subsection{Privacy Concerns}

The concept of privacy concerns was first used in The Right to Privacy written by L. Brandeis and S. Warren, it is defined as the right that personal space is not disturbed. Schoeman defined privacy as the control of individuals over the degree of their personal information and private life available to others.

For years, companies have worked to improve their products and services by collecting customer information. However, because the development of Internet reduces the cost to collect, store, use, and spread personal information, individual privacy is faced with new challenges. In other words, the personal information of consumers may be collected, shared and spread without consumers' awareness. Consumers' increasingly weakened control over their personal information is regarded as one of the risks of the Internet, and consumers' privacy concerns have aroused wide attention in the network environment (Caudill, 2000).

According to an investigation in $2018,85 \%$ of Chinese netizens said they were more alert to individual privacy than before. $92 \%$ of respondents realized the importance that companies return the right to control consumers' personal information to consumers themselves, and $40 \%$ thought that consumers' right to control their own personal information was extremely important. However, although a great number of consumers shared worries about privacy, $62 \%$ of respondents were willing to sell or provide their geographic position (53\%), browsing history $(50 \%)$ and other information to companies. Therefore, it can be concluded that different degrees of consumers concerns about privacy will influence their attitudes towards online cause-related marketing.

\section{Hypotheses and Research Model}


Functional benefits refer to the convenience and effectiveness that consumers perceive when they participate in online cause-related marketing activities. Realtime Internet allows consumers to participate in activities anytime, anywhere. At the same time, various presentation modes improve the reliability of information and improve the perceived effectiveness of online cause-related marketing (Jietang and Sujie, 2018). According to existing research, it is much easier for convenient services to be used by consumers, making it easier to improve consumer satisfaction (Jietang and Sujie, 2018). Meanwhile, convenience and effectiveness perceived on the Internet can have positive effects on consumers' perceived value and consumption intentions (Jietang and Sujie, 2018). This study hypothesized:

H1: Perceived functional benefits of online cause-related marketing will have a positive influence on consumers' attitudes towards Internet cause-related marketing.

Experiential benefits refer to sensory and epistemic satisfactions that consumers perceive when they participate in online cause-related marketing activities (Park et.al, 1986). Consumers can gain a sense of achievement, interest and happiness through finishing various kinds of tasks. Abundant information allows consumers to gain knowledge about public welfare programs more easily, which satisfies their curiosities and helps them achieve epistemic satisfaction. According to existing research, sensory satisfaction and epistemic satisfaction are regarded as important factors that influence consumers' decisions, as they promote consumers to have good attitudes by arousing positive emotions (Park et.al, 1986). Therefore, this study hypothesized:

H2: Perceived experiential benefits of online cause-related marketing will positively influence consumers' attitudes towards Internet cause-related marketing.

Symbolic benefits refer to benefits that can satisfy consumers' needs to express themselves and to be appreciated. In participating in online cause-related marketing, consumers can share their socially responsible activities on social networking services (SNS) in order to receive positive assessments from others. The existing research shows that although symbolic benefits are not a fundamental requirement of consumers, they are still of great significance and are an important impetus that drives consumers to make decisions (Park et.al, 1986). Research on green consumption and ethical fashion has demonstrated that efficiently receiving admiration from others can positively influence consumers' attitudes ((Yoo et.al, 2013); Moon et.al, 2013). Therefore, this study hypothesized:

H3: Perceived symbolic benefits of online cause-related marketing will positively influence consumers' attitudes towards Internet cause-related marketing.

Consumer attitudes refers to consumers' subjective assessments about online cause-related marketing. Concretely, attitudes are an estimate of whether a consumer likes or dislikes the object that is being evaluated, including their general opinions and internal emotions (Engel et.al, 2001). Participation intentions refer to 
consumers' intentions to continuously participate in online cause-related marketing activities and recommend them to others. Participation refers to the degree of consumers' involvement in the actual participation process, including invested time and energy. Research in the field of consumer behaviours has demonstrated that attitudes are closely related to purchasing intentions, purchasing behaviours and recommendation intentions (Boulding et.al, 1993). Therefore, this research hypothesized that the more positive attitudes consumers had, the stronger willingness and deeper participation they would have.

H4: Consumers' friendly attitudes towards online cause-related marketing will have a positive influence on their participation and participation intentions in online cause-related marketing.

Privacy concerns refer to consumers' worries about disclosure of their personal information and private life (Brandeis et.al, 1890). When consumers participate in online cause-related marketing, they must agree to the company collecting their personal information, so there is risk of personal information disclosure (Caudill, 2000). Meanwhile, during participation, SNS uploading tasks or teamwork tasks may also bring the risk of private life disclosure. When people perceive privacy risks of products or services, they may have negative emotions and reduced acceptability of the products (Mingchi, 2009). Therefore, this research proposed that the positive influence of perceived benefits on attitudes would be reduced due to privacy concerns.

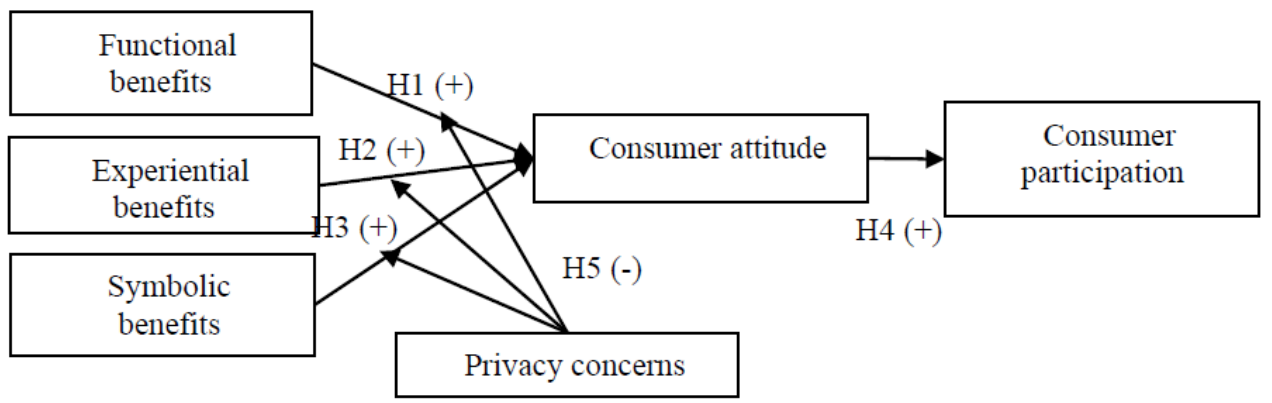

Fig. 1: Research Model.

H5: Consumers' privacy concerns will have a negative moderating influence on the relationship between perceived benefits of online cause-related marketing and consumers' attitudes.

H5-1: Consumers' privacy concerns will reduce the positive influence of perceived functional benefits on consumers' attitudes.

H5-2: Consumers' privacy concerns will reduce the positive influence of perceived experiential benefits on consumers' attitudes. 
H5-3: Consumers' privacy concerns will reduce the positive influence of perceived symbolic benefits on consumers' attitudes.

According to above hypotheses, we developed the research framework as shown in Figure 1.

\section{Methods}

\subsection{Participants and Procedures}

The data was collected via an online questionnaire survey system in China, Wenjuanxing (wjx.cn). It took 3 weeks to collect 535 questionnaires. After removing 18 questionnaires determined to be invalid because the respondent provided the same answer to every question, 517 questionnaires were used for analysis.

The sample included 234 males (45.26\%) and 283 females (54.74\%). 51.84\% of the participants ranged from 18 to 30 years of age, and $37.91 \%$ ranged from $31-50$ years old. Most participants lived in North (43.8\%) and Southwest China $(32.3 \%)$, and had at least a bachelor's degree (78.72\%). 30.03\% were students or job seekers, $39.93 \%$ were company employees with ordinary monthly income (less than 9000yuan), and others were retirees or housewives (30.04\%) [Table I]. The primary online cause-related marketing activity that respondents had taken part in or had heard about was Alipay's Ant Forest, and the second most common was Wechat's Donating Steps.

\subsection{Measures and data analysis}

In this study, we investigated consumers who had participated in and had not participated in online cause-related marketing activities. The questionnaire included introduction of research, informed consent and questions to measure perceived benefits, privacy concerns, consumer attitudes, and consumer participation. Demographic items collected were related to gender, age, monthly income, geographic location, and education level. The questionnaire also included questions about interviewee's participation in other pro-social activities apart from online cause-related marketing: Have you taken part in a charity sale or volunteer activities? How much money/time have you spent on charity sales/volunteer activities at most?

Perceived benefits (functional, experiential, symbolic) were measured by 18 items that were adopted from Zhu and Zhang's scale and Park, Jaworski and Innis Mac's scale. For example, "It is easy/convenient/enjoyable/ to participate in." Privacy concern was measured by 6 items adopted from Fortes and Rita's scale. The sample is "I'm afraid my personal information will be used leaked/ my personal space will be encroached." Consumer attitudes were measured by 4 items adopted from Lee's scale, and the example is "Totally, I think this activity is good." Consumer participation was measured by 8 items adopted from Zhu's scale and 
questions about participation were divided into two parts: participation intention for people who had no experience with online cause-related marketing, like "I want to take part in this activity.", and participation behavior for people who had previously participated in online cause-related marketing like "I have participated in it by 1-3 times a week." (Jietang and Sujie, 2018). All of the items were measured using a seven-point Likert scale with anchors of (1) strongly disagree and (7) strongly agree.

We used multistage process to assess construct validity. We first performed an exploratory factor analysis (EFA). Then, we conducted confirmatory factor analysis (CFA) to test the unidimensionality and convergent validity of the constructs. We assessed the reliability of the constructs by Cronbach's coefficient alpha. The hypotheses were tested by structural equation modeling (SEM) analysis and the moderating effects of privacy concerns were tested by hierarchical regression analysis.

\section{Results}

\subsection{Experienced Group}

\subsubsection{Reliability and Validity Test}

In the reliability assessment, all the scales showed good reliabilities, with high alpha coefficients exceeding $0.7(\alpha>0.7)$ [Table 2]. We conducted a principal component analysis (PCA) and varimax rotation for EFA. After removing 3 items from experiential benefits, 2 items from privacy concerns and 2 items from participation, all the indicators responded to the constructs that they were purported to measure. [Table 2]. CFA results indicated satisfactory model fit indices, and C.R. and AVE estimates that exceeded applicable level (C.R.>0.7, AVE>0.5) [Table 3].

\subsubsection{Hypotheses Testing}

In the experienced group, where respondents had participated in online causerelated marketing activities previously, three perceived benefits all had a positive influence on consumers' attitudes and participation, reaching statistical significance. Therefore, hypotheses 1, 2, 3 and 4 were all supported [Table 4]. The goodness-offit indices of the model were also acceptable (RMSEA $<0.9$, TLI, CFI, NFI, IFI > 0.9, CMIN/DF < 3) [Table 4] (Jijun, 2008).

The moderating effects of privacy concerns were examined by hierarchical regression analysis. In step 1 , the independent variables were put into model 1 . In step 2, the moderator variable was put into model 2. And in step 2, the product of independent variables and moderating variable were put into model 3. After mean centering process, the value of VIF showed that there was no multi-collinearity in the dataset (VIF <10) (Jijun, 2008). In the experienced group, privacy concerns had a significant negative moderating effect on the impact of functional benefits on 
attitudes. However, contrary to H5-3, a significant positive moderating effect on the impact of symbolic benefits on attitudes was found. In other words, privacy concerns weakened the impact of perceived functional benefits, but strengthened the impact of perceived symbolic benefits on consumer attitudes [Table 5].

Table.1: Respondents Characteristics

\begin{tabular}{|c|c|c|c|c|}
\hline & Items & $\begin{array}{l}\text { Experienced } \\
\text { group }\end{array}$ & $\begin{array}{c}\text { Inexperienced } \\
\text { group }\end{array}$ & Total \\
\hline $\mathrm{N}$ & & $\begin{array}{c}267 \\
(100 \%)\end{array}$ & $250(100 \%)$ & $517 \quad(100 \%)$ \\
\hline \multirow[t]{2}{*}{ Gender } & Male & $119(44.6 \%)$ & $115(46 \%)$ & $234(45.26)$ \\
\hline & Female & $148(55.4 \%)$ & $135(54 \%)$ & $283(54.74 \%)$ \\
\hline \multirow[t]{5}{*}{ Age } & Under 18years & $5(1.9 \%)$ & $2(0.8 \%)$ & $7(1.35 \%)$ \\
\hline & $18-30$ & $147(55.1 \%)$ & $121(48.5 \%)$ & $268(51.84 \%)$ \\
\hline & $31-40$ & $44(16.5 \%)$ & $63(25.2 \%)$ & $107(20.7 \%)$ \\
\hline & $41-50$ & $41(15.4 \%)$ & $48(19.2 \%)$ & $89(17.21 \%)$ \\
\hline & Over 51years & $30(11.3 \%)$ & $16(6.4 \%)$ & $46(8.9 \%)$ \\
\hline \multirow{5}{*}{$\begin{array}{l}\text { Education } \\
\text { level }\end{array}$} & Under high school & $15(5.6 \%)$ & $4(1.6 \%)$ & $19(3.68 \%)$ \\
\hline & High school & $31(11.6 \%)$ & $60(24.2 \%)$ & $91(17.6 \%)$ \\
\hline & Bachelor & $143(53.6 \%)$ & $128(51.2 \%)$ & $271 \quad(52.42 \%)$ \\
\hline & Master & $57(21.3 \%)$ & $49(19.6 \%)$ & $106(20.5 \%)$ \\
\hline & Over master & $21(7.9 \%)$ & $9(3.6 \%)$ & $30(5.8 \%)$ \\
\hline \multirow{7}{*}{ Job } & Student & $78(29.3 \%)$ & $54(21.6 \%)$ & $132(25.53 \%)$ \\
\hline & $\begin{array}{l}\text { Company } \\
\text { employees }\end{array}$ & $92(34.5 \%)$ & $58(23.2 \%)$ & $150(29.1 \%)$ \\
\hline & Researcher & $34(12.7 \%)$ & $22(8.8 \%)$ & $56(10.83 \%)$ \\
\hline & $\begin{array}{c}\text { Individual } \\
\text { business }\end{array}$ & $22(8.2 \%)$ & $35(14 \%)$ & $57(11.0 \%))$ \\
\hline & Housewife & $5(1.9 \%)$ & $9(3.6 \%)$ & $14(2.7 \%)$ \\
\hline & Job hunter & $6(2.2 \%)$ & $17(6.8 \%)$ & $23(4.5 \%)$ \\
\hline & Other & $30(11.2 \%)$ & $55(22 \%)$ & $85(16.4 \%)$ \\
\hline \multirow{5}{*}{ Income } & $<=6000$ yuan & $156(58.4 \%)$ & $60(24 \%)$ & $216(41.8 \%)$ \\
\hline & $6001-9000$ & $65(24.3 \%)$ & $128(51.2 \%)$ & $193(37.3 \%)$ \\
\hline & $9001-12000$ & $33(12.4 \%)$ & $49(19.6 \%)$ & $82(15.9 \%)$ \\
\hline & $12001-15000$ & $10(3.7 \%)$ & $9(3.6 \%)$ & $19(3.7 \%)$ \\
\hline & $>=15001$ yuan & $3(1.1 \%)$ & $4(1.6 \%)$ & $7(1.4 \%)$ \\
\hline \multirow{6}{*}{ Location } & East & $15(5.62)$ & $33(13.2 \%)$ & $48(9.3 \%)$ \\
\hline & South & $0(0.00 \%)$ & $23(9.2 \%)$ & $23(4.5 \%)$ \\
\hline & North & $113(42.32 \%)$ & $113(45.2 \%)$ & $226(43.8 \%)$ \\
\hline & Southwest & $2(0.75 \%)$ & $9(3.6 \%)$ & $11(2.1 \%)$ \\
\hline & Northeast & 0 & $42(16.8 \%)$ & $42(8.1 \%)$ \\
\hline & Southwest & $137(51.31 \%)$ & $30(12 \%)$ & $167(32.3 \%)$ \\
\hline
\end{tabular}


Table.2: Reliability and Exploratory Factor Analysis (Experienced Group)

\begin{tabular}{|c|c|c|c|c|c|c|c|c|}
\hline & & 1 & 2 & 3 & 4 & 5 & 6 & $\begin{array}{c}\text { Cronbach's } \\
\text { alpha }\end{array}$ \\
\hline \multirow{7}{*}{$\begin{array}{c}\text { Functional } \\
\text { benefits }\end{array}$} & Function 1 & 0.746 & 0.217 & 0.216 & -0.088 & 0.258 & 0.042 & 0.873 \\
\hline & Function2 & 0.778 & 0.242 & 0.265 & -0.083 & 0.172 & 0.044 & \\
\hline & Function3 & 0.666 & 0.339 & 0.302 & -0.003 & 0.234 & -0.061 & \\
\hline & Function4 & 0.778 & 0.262 & 0.171 & -0.062 & 0.099 & 0.034 & \\
\hline & Function5 & 0.780 & 0.232 & 0.210 & -0.093 & 0.197 & 0.007 & \\
\hline & Function6 & 0.664 & 0.406 & 0.271 & -0.066 & 0.114 & -0.068 & \\
\hline & Function7 & 0.677 & 0.293 & 0.195 & -0.002 & 0.395 & 0.146 & \\
\hline \multirow{4}{*}{$\begin{array}{l}\text { Experiential } \\
\text { benefits }\end{array}$} & Experience1 & 0.521 & 0.274 & 0.302 & -0.081 & 0.597 & 0.036 & 0.852 \\
\hline & Experience2 & 0.407 & 0.300 & 0.343 & -0.039 & 0.663 & 0.056 & \\
\hline & Experience3 & 0.340 & 0.300 & 0.322 & -0.112 & 0.712 & 0.047 & \\
\hline & Experience4 & 0.360 & 0.305 & 0.243 & -0.083 & 0.718 & 0.047 & \\
\hline \multirow{6}{*}{$\begin{array}{l}\text { Symbolic } \\
\text { benefits }\end{array}$} & Symbol1 & 0.246 & 0.791 & 0.259 & -0.034 & 0.261 & 0.053 & 0.935 \\
\hline & Symbol2 & 0.302 & 0.782 & 0.229 & -0.017 & 0.238 & 0.079 & \\
\hline & Symbol3 & 0.241 & 0.740 & 0.256 & -0.011 & 0.368 & -0.059 & \\
\hline & Symbol4 & 0.326 & 0.813 & 0.239 & -0.055 & 0.111 & -0.061 & \\
\hline & Symbol5 & 0.292 & 0.844 & 0.208 & -0.002 & 0.125 & -0.069 & \\
\hline & Symbol6 & 0.324 & 0.773 & 0.300 & -0.008 & 0.070 & -0.015 & \\
\hline \multirow{4}{*}{$\begin{array}{l}\text { Privacy } \\
\text { concerns }\end{array}$} & Privacy1 & 0.182 & 0.152 & 0.427 & 0.661 & 0.009 & -0.041 & 0.957 \\
\hline & Privacy 2 & -0.126 & -0.036 & -0.090 & 0.904 & -0.095 & -0.047 & \\
\hline & Privacy3 & -0.106 & -0.071 & -0.155 & 0.921 & -0.025 & -0.080 & \\
\hline & Privacy4 & -0.131 & -0.071 & -0.163 & 0.914 & -0.052 & -0.041 & \\
\hline \multirow[t]{5}{*}{ Attitude } & attitude1 & 0.301 & 0.196 & 0.727 & -0.072 & 0.186 & 0.045 & 0.921 \\
\hline & attitude2 & 0.278 & 0.280 & 0.742 & -0.056 & 0.261 & 0.037 & \\
\hline & attitude3 & 0.309 & 0.242 & 0.771 & -0.080 & 0.238 & -0.047 & \\
\hline & attitude4 & 0.228 & 0.341 & 0.780 & -0.077 & 0.154 & -0.041 & \\
\hline & attitude 5 & 0.240 & 0.370 & 0.690 & -0.068 & 0.155 & -0.026 & \\
\hline \multirow[t]{4}{*}{ Participation } & intention 1 & 0.070 & -0.054 & 0.035 & -0.082 & 0.022 & 0.919 & 0.726 \\
\hline & intention2 & -0.035 & 0.054 & -0.051 & -0.072 & 0.025 & 0.899 & \\
\hline & intention3 & 0.039 & -0.047 & -0.004 & -0.017 & 0.039 & 0.853 & \\
\hline & \multicolumn{7}{|c|}{$\mathrm{KMO}=.935$, Bartlett $\mathrm{x}^{2}=6886.543, \mathrm{df}=405, \mathrm{p}=.000$} & \\
\hline
\end{tabular}


Table.3: Confirmatory Factor Analysis (Experienced Group)

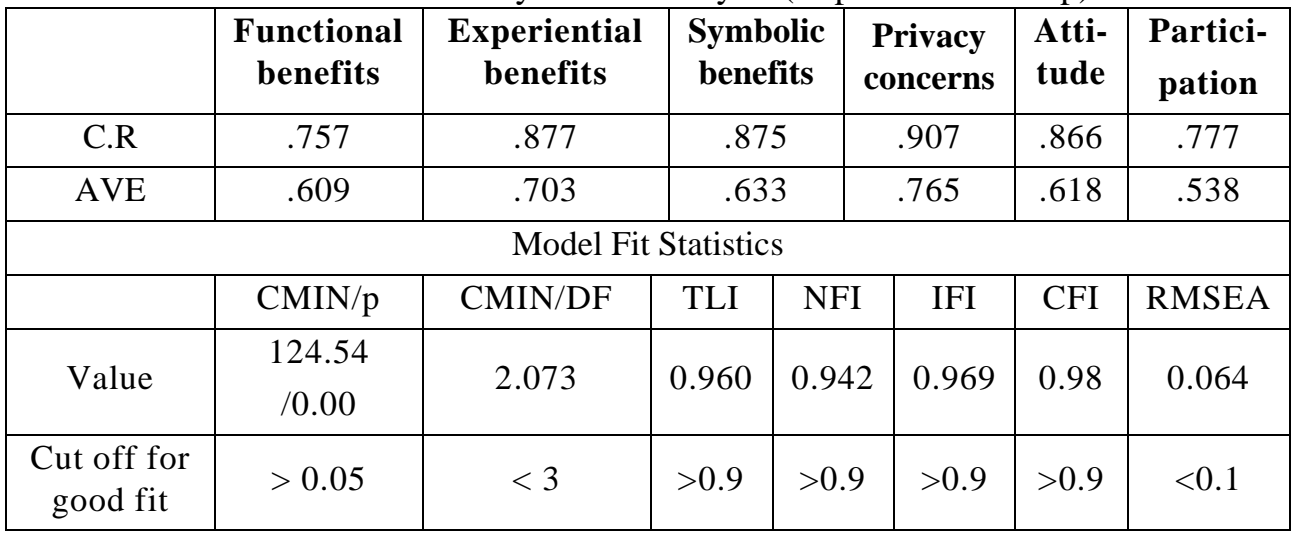

Table.4: Structural Equation Modelling Analysis (Experienced Group)

\begin{tabular}{|c|c|c|c|}
\hline Independent Variables & Dependent Variables & Estimate $(S E)$ & P-value \\
\hline Functional benefits & \multirow{3}{*}{ Attitude } & $.25(.12)$ & .034 \\
\hline Experiential benefits & & $.58(.14)$ & .000 \\
\hline Symbolic benefits & & $.14(.026)$ & .000 \\
\hline Attitude & $\begin{array}{c}\text { Participation } \\
\text { (behavior/intention) }\end{array}$ & $1.034(.087)$ & .000 \\
\hline Goodness-of-fit indices & \multicolumn{3}{|c|}{$\mathrm{TLI}=.96, \mathrm{NFI}=.94, \mathrm{IFI}=.97, \mathrm{CFI}=.98, \mathrm{RMSEA}=.064$} \\
\hline
\end{tabular}

\subsection{Inexperienced Group}

\subsubsection{Reliability and Validity Test}

In the reliability assessment, all the scales showed good reliabilities, with high alpha coefficients exceeding $0.7(\alpha>0.7)$ [Table 6]. We conducted a principal component analysis (PCA) and varimax rotation for EFA. After removing 3 items from experiential benefits, 1 item from privacy concerns and 1 item from participation intention, all the indicators responded to the constructs that they were purported to measure. [Table 6]. CFA results indicated satisfactory model fit indices, and C.R. and AVE estimates that exceeded applicable level (C.R.>0.7, AVE>0.5) [Table 7].

\subsubsection{Hypotheses Test}

In the inexperienced group, where respondents had not participated in online causerelated marketing activities previously, the results of hypothesis test are as below. Only perceived experiential benefits and symbolic benefits had a positive influence on consumers' attitudes and participation intention, reaching statistical significance. Hypothesis 1 was not supported, and hypotheses 2, 3 and 4 were supported [Table 
8]. Perceived experiential benefits were found to be the most influential. The goodness-of-fit indices of the model were also acceptable (RMSEA < 0.9, TLI, CFI, NFI, IFI > 0.9, CMIN/DF < 3) [Table 8] (Jijun, 2008).

Table.5: Hierarchical Regression Analysis Results (Experienced Group)

\begin{tabular}{|c|c|c|c|c|c|c|c|c|c|c|c|c|}
\hline & \multicolumn{4}{|c|}{ Model 1} & \multicolumn{4}{|c|}{ Model 2} & \multicolumn{4}{|c|}{ Model 3} \\
\hline & $\beta$ & $t$ & $\mathbf{P}$ & VIF & $\beta$ & $t$ & $\mathbf{P}$ & VIF & $\boldsymbol{\beta}$ & $t$ & $\mathbf{P}$ & VIF \\
\hline Constant & & 172.50 & .000 & & & 172 & .000 & & & 172.60 & .000 & \\
\hline $\begin{array}{l}\text { Functional } \\
\text { benefits }\end{array}$ & .33 & 6.66 & .000 & 1.878 & .33 & 6.60 & .000 & 1.881 & .31 & 6.27 & .000 & 2.099 \\
\hline $\begin{array}{l}\text { Experiential } \\
\text { benefits }\end{array}$ & .29 & 5.66 & .000 & 1.529 & .29 & 5.6 & .000 & 1.539 & .31 & 5.93 & .000 & 1.790 \\
\hline $\begin{array}{l}\text { Symbolic } \\
\text { benefits }\end{array}$ & .33 & 7.59 & .000 & 1.420 & .33 & 7.58 & .000 & 1.454 & .36 & 8.12 & .000 & 1.617 \\
\hline $\begin{array}{l}\text { Privacy } \\
\text { concerns }\end{array}$ & & & & & .008 & .21 & .834 & 1.219 & .027 & .59 & .557 & 1.493 \\
\hline $\begin{array}{l}\text { Functional } \\
\text { benefits x } \\
\text { Privacy } \\
\text { concerns }\end{array}$ & & & & & & & & & -.12 & -2.15 & .032 & 1.928 \\
\hline $\begin{array}{l}\text { Experiential } \\
\text { benefits } \mathrm{x} \\
\text { Privacy } \\
\text { concerns }\end{array}$ & & & & & & & & & - & -.53 & .595 & 2.084 \\
\hline $\begin{array}{l}\text { Symbolic } \\
\text { benefits x } \\
\text { Privacy } \\
\text { concerns }\end{array}$ & & & & & & & & & .15 & 3.07 & .002 & 1.527 \\
\hline$R^{2}$ & \multicolumn{4}{|l|}{.57} & \multicolumn{4}{|l|}{.57} & \multicolumn{4}{|l|}{.59} \\
\hline Change in $R^{2}$ & \multicolumn{4}{|l|}{.57} & \multicolumn{4}{|l|}{.000} & \multicolumn{4}{|l|}{.019} \\
\hline Change in $F$ & \multicolumn{4}{|c|}{$118.80(\mathrm{p}=.000)$} & \multicolumn{4}{|c|}{$.044(\mathrm{p}=.11)$} & \multicolumn{4}{|c|}{$4.14(\mathrm{p}=.01)$} \\
\hline
\end{tabular}

The moderating effects of privacy concerns were examined by hierarchical regression analysis. In step 1 , the independent variables were put into model 1 . In step 2, the moderating variable was put into model 2. And in step 3, the product of independent variables and moderator variable were put into model 3. After mean centering process, the value of VIF showed that there is no multi-collinearity in the dataset (VIF <10) (Jijun, 2008). In the group of inexperienced respondents, no obvious moderating effect on functional and experiential benefits was identified and 
the influence on symbolic benefits shows statistically significant potentiation, which was different from the hypothesized result [Table 9].

Table. 6: Reliability and Exploratory Factor Analysis (Inexperienced Group)

\begin{tabular}{|c|c|c|c|c|c|c|c|c|}
\hline & & 1 & 2 & 3 & 4 & 5 & 6 & $\begin{array}{c}\text { Cronbach's } \\
\text { alpha }\end{array}$ \\
\hline \multirow{7}{*}{$\begin{array}{c}\text { Functional } \\
\text { benefits }\end{array}$} & Function 1 & 0.746 & 0.217 & 0.216 & -0.088 & 0.258 & 0.042 & 0.951 \\
\hline & Function2 & 0.778 & 0.242 & 0.265 & -0.083 & 0.172 & 0.044 & \\
\hline & Function3 & 0.666 & 0.339 & 0.302 & -0.003 & 0.234 & -0.061 & \\
\hline & Function4 & 0.778 & 0.262 & 0.171 & -0.062 & 0.099 & 0.034 & \\
\hline & Function5 & 0.780 & 0.232 & 0.210 & -0.093 & 0.197 & 0.007 & \\
\hline & Function6 & 0.664 & 0.406 & 0.271 & -0.066 & 0.114 & -0.068 & \\
\hline & Function7 & 0.677 & 0.293 & 0.195 & -0.002 & 0.395 & 0.146 & \\
\hline \multirow{4}{*}{$\begin{array}{l}\text { Experiential } \\
\text { benefits }\end{array}$} & Experience1 & 0.521 & 0.274 & 0.302 & -0.081 & 0.597 & 0.036 & 0.958 \\
\hline & Experience2 & 0.407 & 0.300 & 0.343 & -0.039 & 0.663 & 0.056 & \\
\hline & Experience 3 & 0.340 & 0.300 & 0.322 & -0.112 & 0.712 & 0.047 & \\
\hline & Experience4 & 0.360 & 0.305 & 0.243 & -0.083 & 0.718 & 0.047 & \\
\hline \multirow{6}{*}{$\begin{array}{l}\text { Symbolic } \\
\text { benefits }\end{array}$} & Symbol1 & 0.246 & 0.791 & 0.259 & -0.034 & 0.261 & 0.053 & 0.961 \\
\hline & Symbol2 & 0.302 & 0.782 & 0.229 & -0.017 & 0.238 & 0.079 & \\
\hline & Symbol3 & 0.241 & 0.740 & 0.256 & -0.011 & 0.368 & -0.059 & \\
\hline & Symbol4 & 0.326 & 0.813 & 0.239 & -0.055 & 0.111 & -0.061 & \\
\hline & Symbol5 & 0.292 & 0.844 & 0.208 & -0.002 & 0.125 & -0.069 & \\
\hline & Symbol6 & 0.324 & 0.773 & 0.300 & -0.008 & 0.070 & -0.015 & \\
\hline \multirow{4}{*}{$\begin{array}{l}\text { Privacy } \\
\text { concerns }\end{array}$} & Privacy 1 & 0.182 & 0.152 & 0.427 & 0.661 & 0.009 & -0.041 & 0.809 \\
\hline & Privacy2 & -0.126 & -0.036 & -0.090 & 0.904 & -0.095 & -0.047 & \\
\hline & Privacy3 & -0.106 & -0.071 & -0.155 & 0.921 & -0.025 & -0.080 & \\
\hline & Privacy4 & -0.131 & -0.071 & -0.163 & 0.914 & -0.052 & -0.041 & \\
\hline \multirow[t]{5}{*}{ Attitude } & attitude1 & 0.301 & 0.196 & 0.727 & -0.072 & 0.186 & 0.045 & 0.949 \\
\hline & attitude2 & 0.278 & 0.280 & 0.742 & -0.056 & 0.261 & 0.037 & \\
\hline & attitude3 & 0.309 & 0.242 & 0.771 & -0.080 & 0.238 & -0.047 & \\
\hline & attitude 4 & 0.228 & 0.341 & 0.780 & -0.077 & 0.154 & -0.041 & \\
\hline & attitude5 & 0.240 & 0.370 & 0.690 & -0.068 & 0.155 & -0.026 & \\
\hline \multirow[t]{3}{*}{ Participation } & intention1 & 0.070 & -0.054 & 0.035 & -0.082 & 0.022 & 0.919 & 0.711 \\
\hline & intention2 & -0.035 & 0.054 & -0.051 & -0.072 & 0.025 & 0.899 & \\
\hline & intention3 & 0.039 & -0.047 & -0.004 & -0.017 & 0.039 & 0.853 & \\
\hline
\end{tabular}


Table.7: Confirmatory Factor Analysis (Inexperienced Group)

\begin{tabular}{|c|c|c|c|c|c|c|c|}
\hline & $\begin{array}{c}\text { Functional } \\
\text { benefits }\end{array}$ & $\begin{array}{c}\text { Experientia } \\
\text { benefits }\end{array}$ & \multicolumn{2}{|c|}{$\begin{array}{c}\text { Symbolic } \\
\text { benefits }\end{array}$} & $\begin{array}{l}\text { Privacy } \\
\text { concerns }\end{array}$ & $\begin{array}{l}\text { Atti- } \\
\text { tude }\end{array}$ & $\begin{array}{l}\text { Partici } \\
\text {-pation }\end{array}$ \\
\hline C.R & .781 & .891 & \multicolumn{2}{|c|}{.875} & .869 & .861 & .777 \\
\hline AVE & .544 & .731 & \multicolumn{2}{|c|}{.637} & .688 & .674 & .538 \\
\hline \multicolumn{8}{|c|}{ Model Fit Statistics } \\
\hline & $\mathrm{CMIN} / \mathrm{p}$ & $\begin{array}{c}\text { CMIN/D } \\
\mathrm{F} \\
\end{array}$ & TLI & NFI & IFI & CFI & $\begin{array}{c}\text { RMS } \\
\text { EA }\end{array}$ \\
\hline Value & $\begin{array}{c}202.544 / 0 . \\
00\end{array}$ & 2.276 & 0.965 & 0.951 & 0.972 & 0.972 & 0.059 \\
\hline $\begin{array}{c}\text { Cut off for } \\
\text { good fit }\end{array}$ & $>0.05$ & $<3$ & $>0.9$ & $>0.9$ & $>0.9$ & $>0.9$ & $<0.1$ \\
\hline
\end{tabular}

Table.8: Structural Equation Modeling Analysis Result (Inexperienced Group)

\begin{tabular}{|c|c|c|c|}
\hline Independent Variables & Dependent Variables & Estimate $(S E)$ & P-value \\
\hline Functional benefits & \multirow{3}{*}{ Attitude } & $.076(.12)$ & .486 \\
\hline Experiential benefits & & $.45(.073)$ & .000 \\
\hline Symbolic benefits & & $.22(.071)$ & .002 \\
\hline Attitude & $\begin{array}{c}\text { Participation } \\
\text { (behavior/intention) }\end{array}$ & $.24(.066)$ & .000 \\
\hline $\begin{array}{l}\text { Goodness-of- Fit } \\
\text { Indices }\end{array}$ & \multicolumn{3}{|c|}{$\begin{array}{c}\mathrm{TLI}=.97, \mathrm{NFI}=.95, \mathrm{IFI}=.97, \mathrm{CFI}=.97 \\
\mathrm{RMSEA}=.006\end{array}$} \\
\hline
\end{tabular}

\subsubsection{Additional Analysis}

The perceptions of online cause-related marketing activities between two groups were compared using a t-test. Results showed that respondents who had participated in online cause-related marketing activities had higher perceived benefits and more positive attitudes about these activities than respondents who had not participated in this kind of activity $(\mathrm{p}<.05)$. The study also compared respondents' involvement in other pro-social activities between two groups using a chi-square test. The results revealed that compared with people who never participated in online cause-related marketing activities, the people who had participated donated less money in other donation activities $(\mathrm{t}=73.75, \mathrm{p}<.001)$ and spent less time in actual volunteer activities $(\mathrm{t}=30.05, \mathrm{p}<.001)$. Additionally, the people who had participated in online cause-related marketing activities preferred to spend more time on the Internet everyday $(\mathrm{t}=46.57, \mathrm{p}<.001)$. 
One possible conclusion may be that people who want to do something "kind" but are reluctant to spend too much on charitable activities prefer the online causerelated marketing activities, which can save them time and money. Or involvement in the online cause-related marketing activities may limit their additional donations.

Table.9: Hierarchical Regression Analysis Results (Inexperienced Group)

\begin{tabular}{|c|c|c|c|c|c|c|c|c|c|c|c|c|}
\hline & \multicolumn{2}{|c|}{ Model1 } & \multirow[b]{2}{*}{$\mathbf{P}$} & \multirow[b]{2}{*}{ VIF } & \multicolumn{2}{|c|}{ Model2 } & \multirow[b]{2}{*}{$\mathbf{P}$} & \multirow[b]{2}{*}{ VIF } & \multicolumn{2}{|c|}{ Model3 } & \multirow[b]{2}{*}{$\mathbf{P}$} & \multirow[b]{2}{*}{ VIF } \\
\hline & $\beta$ & $t$ & & & $\beta$ & $t$ & & & $\boldsymbol{\beta}$ & $t$ & & \\
\hline Constant & & 92.82 & .000 & & & 92.69 & .000 & & & 91.58 & .000 & \\
\hline $\begin{array}{l}\text { Functional } \\
\text { benefits }\end{array}$ & .044 & .63 & .531 & 1.478 & .040 & .57 & .573 & 1.253 & .029 & .41 & .683 & 1.348 \\
\hline $\begin{array}{l}\text { Experiential } \\
\text { benefits }\end{array}$ & .46 & 7.023 & .000 & 1.357 & .46 & 6.86 & .000 & 3.369 & .46 & 7.039 & .000 & 3.930 \\
\hline $\begin{array}{l}\text { Symbolic } \\
\text { benefits }\end{array}$ & .35 & 5.22 & .000 & 1.008 & .35 & 5.24 & .000 & 3.055 & .36 & 5.50 & .000 & 3.097 \\
\hline $\begin{array}{l}\text { Privacy } \\
\text { concerns }\end{array}$ & & & & & -.023 & -.55 & .583 & 3.085 & $\begin{array}{l}- \\
.026 \\
\end{array}$ & -.64 & .524 & 43.079 \\
\hline $\begin{array}{l}\text { Functional } \\
\text { benefits } \mathrm{x} \\
\text { Privacy } \\
\text { concerns }\end{array}$ & & & & & & & & & -.14 & -1.68 & & 1.216 \\
\hline $\begin{array}{l}\text { Experiential } \\
\text { benefits } \mathrm{x} \\
\text { Privacy } \\
\text { concerns }\end{array}$ & & & & & & & & & .004 & .049 & .961 & 4.732 \\
\hline $\begin{array}{l}\text { Symbolic } \\
\text { benefits x } \\
\text { Privacy } \\
\text { concerns }\end{array}$ & & & & & & & & & .24 & 3.093 & .002 & 1.144 \\
\hline \multicolumn{2}{|l|}{$R^{2}$} & \multicolumn{4}{|l|}{.62} & \multicolumn{3}{|l|}{.62} & \multicolumn{4}{|c|}{.65} \\
\hline \multicolumn{2}{|l|}{ Change in $R^{2}$} & \multicolumn{4}{|c|}{.62} & \multicolumn{3}{|c|}{.000} & \multicolumn{2}{|c|}{.023} & & \\
\hline \multicolumn{2}{|l|}{ Change in F } & \multicolumn{4}{|c|}{$132.91(\mathrm{p}=.000)$} & \multicolumn{3}{|c|}{$.30(\mathrm{p}=.21)$} & \multicolumn{4}{|c|}{$5.51(\mathrm{p}=.001)$} \\
\hline Durbin-Wats & 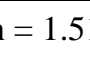 & & & & & & & & & & & \\
\hline
\end{tabular}




\section{Discussion}

To gain a deeper understanding of consumers' participation in online cause-related marketing, this study examined the influence of perceived benefits and privacy concerns on consumer attitudes, participation and participation intentions.

Regarding the influence of perceived benefits on consumers' attitudes and consumer participation, we discovered that for people who had participated in online cause-related marketing activities, the higher functional, experiential and symbolic benefits they can perceive, the more positive their attitudes were and the higher degree of participation they reported. However, for people without experience, only the higher experiential and symbolic benefits they perceived led to more positive attitudes and higher intention to participate.

Regarding the moderating effect of privacy concerns, for experienced individuals, privacy concerns weakened the influence of functional benefits on consumer attitudes, and increased the influence of symbolic benefits on attitudes. For inexperienced people, privacy concerns enhanced the influence of symbolic benefits. As for why the influence of functional benefits on attitudes was weakened by privacy concerns, a reasonable inference is that functional benefits are related to convenience or effectiveness. Therefore, if consumers perceive the privacy risk taken by personal information disclosure, the perceived participation cost of online cause-related marketing will be higher and the effect of functional benefits is reduced (Jeong-Ju et.al, 2013).

There are a few possible reasons why the influence of symbolic benefits on attitudes was strengthened by privacy concerns. Symbolic benefits refer to benefits that consumers receive by sharing themselves and being approved by others (Park et.al, 1986). Privacy concerns refer to consumers' concerns caused by excessive disclosure of their personal information (Brandeis et.al, 1890). Therefore, when consumers learn that they will probably be seen by others when participating in online cause-related marketing, their perceived symbolic benefits and privacy concerns will both increase. Hence, it is much easier for consumers with higher privacy concerns to perceive symbolic benefits, and their attitudes towards online cause-related marketing will be influenced more.

This study did not find that privacy concerns had a moderating effect on experiential benefits. Meanwhile, compared with other benefits, experiential benefits had the most direct influence on attitudes. Therefore, it is possible that the effect of experiential benefits is so strong that it is difficult for this variable to be influenced by other factors.

This study contributes to the field in multiple ways. First, it elucidates consumers' motivations when participating in cause-related marketing activities from the perspective of perceived benefits. Although perceived benefits are always important criteria for consumers when choosing products, few researchers have 
studied the perceived benefits of cause-related marketing. This research, based on theories of Park, Jaworski and Innis Mac's study of perceived benefits, identified three perceived benefits of online cause-related marketing and tested how these perceived benefits influenced consumers' attitudes and participation.

Furthermore, the research investigated the influence of privacy concerns, a factor not previously mentioned in relation to cause-related marketing. Many companies are attempting to provide individual customized services for consumers, and they must consider whether consumers are willing to accept these kinds of services. This research is meaningful as it illustrates the role of consumers' privacy concerns in cause-related marketing.

Finally, this research discovered the reinforcing effect of privacy concerns on symbolic benefits. It provided a deep and novel understanding of consumers' mentality, motivations, and behaviors related to online cause-related marketing.

Some practical suggestions follow from these findings. First, in order to efficiently promote consumer participation, companies should actively provide functional benefits, experiential benefits and symbolic benefits for consumers, particularly experiential benefits. Experiential benefits can influence consumers' attitudes towards cause-related marketing more efficiently than functional or symbolic benefits. In recent years, young consumers have become increasingly interested in public welfare activities, so it is necessary to make use of the Internet's instantaneity, flexibility and diversity to develop interesting and creative activity forms that attract more young consumers.

Additionally, when collecting the personal information of consumers, companies should actively manage the problem of information disclosure. In particular, this research demonstrated that when consumers perceive symbolic benefits of activities, their concerns about privacy also increase simultaneously. Therefore, when developing social functions, apart from providing symbolic benefits for consumers, companies should also pay more attention to avoiding arousing consumers' privacy concerns. For example, companies could formulate more detailed and concrete terms to use personal information so as to increase consumers' trust and decrease their concerns. Companies could also consider allowing consumers to decide whether to share their activity with others.

This study does have a few limitations. Firstly, this study used only Chinese samples, so there are some shortcomings in the generalizability of the results. Future studies may investigate these effects in other cultural regions. Secondly, further research examining privacy concerns' moderating effect is still needed.

\section{References}

2018 Norton LifeLock. (2019). Cyber Safety Insights Report. https://us.norton.com/cyber-security-insights-2018 
Albert Wenben, L. (1995). Consumer values, product benefits and customer value: a consumption behavior approach. Advances in Consumer Research, 22.1: 381-388.

Batra, R. and Ahtola, O. T. (1991). Sources of the hedonic and utilitarian measuring attitudes consumer. Marketing Letters, 2.2: 159-170.

Boulding, W., Kalra, A., Staelin, R. and Zeithaml, V. A. (1993). A dynamic process model of service quality: from expectations to behavioral intentions. Journal of marketing research, 30.1: 7-27.

Caudill, Eve M. and Murphy, Patrick E. (2000). Consumer online privacy: Legal and ethical issues. Journal of Public Policy and Marketing, 19.1: 7-19.

China Internet Network Information Center. "The 44th China Internet development report." (2019.08) http://www.cac.gov.cn/2019-08/30/c_1124939590.htm

Cnfina. "Young people's public welfare: Public welfare innovation of ifeng.com." (2017.05) http://www.cnfina.com/kuaixun/20170518_102948.html

Do-seong, W., Wang-jin, Y. and Jong-beom, M.. (2013). A Study of the Satisfaction on the Social Networking Service Cognition to Personality Traits. The E-business studies, 14.2 : 263-285.

Engel, James F., Blackwell, Roger D. and Kollat, D. J. (2001). Consumer Behavior, 3rd. Harcourt College Publishers.

Fei-yun, Ch and Bing, L. (2015). The comparative study of Olympic marketing strategy - takes HengYuanXiang and NongFu Spring as examples. Sports Research and Education, 6.: 39-42.

Ferdinand David, S. (1984). Philosophical Dimensions of Privacy: An Anthology. Cambridge University Press.

Fortes, N. and Rita, P. (2016). Privacy concerns and online purchasing behavior: Towards an integrated model. European Research on Management and Business Economics, 22.3: 167-176.

Hee-kang, M., Ho-jung, Ch., Hye-sun, P. and Eun-soo, B. (2013). The Roles of Benefit and Risk Perception in Ethical Fashion Consumption. Journal of the Korean Society of Clothing and Textiles, 37.2: 159-173.

Innovation is everywhere. "Internet Plus: China's official strategy for the uberisation of the economy." (2015. 05) https://www.innovationiseverywhere.com/internet-plus-chinas-official-strategy-forthe-uberisation-of-the-economy/

Jeong-Ju, Y., Divita, L. and Hye-Young, K. (2013). Environmental awareness on bamboo product purchase intentions: do consumption values impact green 
consumption. International Journal of Fashion Design, Technology and Education, 6.1: 27-34.

Jianfeng, F. and Zhilong, T. Research on Influence of the Matching between Brand and Cause on Effect of -Related Marketing. Contemporary Economy and Management, 32.1 .

Jie-tang, Zh. and Su-jie, Zh. (2018). Research on improving users' participation in network Cause-related marketing. Journal of Zhengzhou University of Aeronautics, 36.4: 61-69.

Ji-jun, S. (2008). SPSS and AMOS statistical analysis method for thesis writing, 2nd. 21 st Century Publishers.

Jing-tao, L. and Li-dong, Zh. (2019). The Influence of Consumer Privacy Concern on Collaborative Consumption Willingness in Sharing Economy - An Empirical Study Based on Didi Chuxing Platform. Journal of Fujian Business University .06: 34-40.

Ju-won, J. and So-yeon, Ch. (2018). Relationship among perceived benefit, perceived risk and continuous use of user' Internet primary bank: The mediation effects of trust. Journal of the Korea Convergence Society, 9.12: 195-205.

Keller, Kevin.L. (1993). Conceptualizing, measuring, and managing customerbased brand equity. Journal of marketing, 57.1: 1-22.

Kun-zhang, Y., Lin, Ch. and Yun-fang, Y. (2009). A Research of the Influence of Customer Trust on Behavior Intention in Cause Related Marketing. Economic Survey .09: 124-127.

Louis Dembitz, B. and Warren, Samuel D. (1890). The Right to Privacy, 4. Harvard Law Review, 4.5: 193-220.

Ming-chi, L. (2009). Factors influencing the adoption of internet banking: An integration of TAM and TPB with perceived risk and perceived benefit. Electronic commerce research and applications, 3.: 130-141.

Park, C. Whan, Jaworski, Bernard J. and MacInnis, D. J. (1986). Strategic brand concept-image Management. Journal of marketing, 50.4: 135-145.

Peter, J. Paul and Olson, Jerry C. (1987). Consumer behavior: marketing strategy perspectives. Irwin Inc.

Philip, K. and Nancy, L. (2005). Best of breed: When it comes to gaining a market edge while supporting a social cause corporate social marketing leads the pack. Social marketing quarterly, 11. 3-4: 91-103. 
Qi, W. and Seong-Yeon, P. (2020). Chinese Cause-Related Marketing through Internet: Perceived Benefits, Participation and Privacy Concerns. International Journal of Smart Business and Technology, 8.1: 21-28.

Sheth, Jagdish N., Newman, Bruce I. and Gross, Barbara L. (1991). Why We Buy What We Buy: A Theory of Consumption Values. Journal of Business Research, 22.2: $159-170$.

Shuang, H. (2018). The Influence of Online Public Welfare on Behavior and Values of Youth-Taking ant forest as an example. The Guide of Science and Education, 05: 148-149.

Tai-hong, L. and Wu-rong, L. (2002). New way of marketing: Cause-related marketing. Business management Journal, 09: 58-60.

Varadarajan, P. R. and Menon, A. (1988). Cause-related marketing: A coalignment of marketing strategy and corporate philanthropy. Journal of Marketing, 52.3: 58-74.

Xiang-ming, R. (2016). Research of Relationship among Information Quality Characteristics, Consumer Involvement and Purchase intention. Journal of Wuhan Business University, 30.3: 54-58.

Yi, H. and Xue-mei, Zh. (2018). Gamification innovation strategy of environmental communication in the Internet environment. Journalism Lover,.02: 77-79.

Yoo, J. J., Divita, L. and Kim, H. Y. (2013). Environmental awareness on bamboo product purchase intentions: do consumption values impact green consumption. International Journal of Fashion Design Technology and Education, 6.1: 27-34.

Yong-qiang, G. (2007). The Cause-related Marketing of Chinese Enterprises. Contemporary Economy and Management, 04: 37-40.

Yong-guang, X. "Three phases and three trends of philanthropy in China." (2016.09) http://www.naradafoundation.org/content/5049 